\title{
Potential of Biogold Nanoparticles to Control Plant Pathogenic Nematodes
}

\section{Rajni Kant Thakur* and Poonam Shirkot}

Department of Biotechnology, Dr. YS Parmar University of Horticulture and Forestry Nauni, Solan, India

\begin{abstract}
Increased uses of chemical pesticide were intensified to increase agriculture output in different crops in new agroecological zones. Pesticides are ineffective to solve the problem of nematodes, as nematodes population increased several months after the nematicidal were used. Due to increased selection pressure, new races of nematodes were developed. So in order to have effective management, nanoparticles offer a lot of potentials to effectively control nematodes population through its targeted approach, nanoparticles mediates higher penetration of chemicals pesticides with a minimum concentration of chemical used, as there penetrates easily through the cell wall and produces maximum effect. Gold nanoparticles kill nematodes itself, but when used along with chemicals nematicides their efficiency increased significantly.
\end{abstract}

\section{Keywords: Nanoparticles; Pesticides; Pathogenic}

\section{Introduction}

Plant pathogenic nematodes are microscopic but mighty as crop losses of $\$ 85$ billion have been estimated worldwide each year. Annual estimated crop losses due to nematodes in India have been worked out to be about Rs 242.1 billion. Nematodes continue to threaten agricultural crops throughout world including tropical and subtropical regions and for centuries they have affected crop plants by feeding on roots, pods, stems, crown, leaves, and seeds. Extensive research in developed countries and more than 70 developing countries have confirmed the concern of destructive nature of PPNs and it has become very significant to manage these to increase crop productivity. Plants pathogenic nematodes are microscopic, worm shaped organisms present within plant materials or rhizospheric soil itself. Out of total known species of nematodes, only $10 \%$ are plants pathogenic in nature and these feed on plants leading to the reduction in the growth of crops and yield efficiency [1]. Females of PPNs carry out the egg laying in the roots and surrounding rhizosphere soil followed by hatching leading to the development of worm like larvae reaching maturity through four moulting's. Survival, growth, and reproduction of nematode largely depends on soil moisture, temperature and plants to be used as food source and mostly underground parts of the plant are the possible food sources, which are consumed using a stylet, a spear like structure that withdraws plants sap juice by sucking leading to weakening of the plant. PPNs can be endoparasitic, semi endoparasitic, semi ectoparasitic or ectoparasitic. PPNs cause injury to the plants which leads to others problems followed by poor crop nutrition, crop management, a status of soil health and various infection affecting plant growth and harvest [2]. Most common PPN species reducing crop productivity are root knot nematodes e.g. Meloidogyne spp., root lesion nematodes e.g. Pratylenchus spp., bulb, and stem infecting Ditylenchus spp., leaves infecting Aphelenchoides spp., dagger shaped Xiphinema spp., lance shaped Hoploaimus spp., citrus nematodes Aphelenchoides spp., ring shaped Criconemoides spp., and growth stunting Tylenchutus spp., crops infected with significantly large nematode population on plant roots weakens the root to take-up water and minerals followed by their transportation to shoots of the plants affecting the crop quality and yield because shoot and root growth is restricted and plant vitality is affected. This leads to unhealthy and not uniform plant growth followed by weakening, chlorosis, and stunting, the formation of knots and galls, lesions on roots, bifurcation of roots leading to poor root health and growth. Meloidogyne spp. commonly known as root knot nematodes is of major serious concern for most of the crops grown in light soils e.g. tomato, okra, cucumber etc. Root knot nematode is sedentary endoparasites whose larva feed on roots and reduce crop productivity and takes 3-4 weeks [3].

\section{Nanoparticles and Management of Different Diseases}

Use of nanoparticles in plant disease management is a novel and fancy approach that may prove very effective in future with the progress of application aspect of nanotechnology [4]. A nematicide is a chemical used to kill plant parasitic nematodes. These are broad spectrum toxicants possessing high volatility or other properties promoting migrating through a soil e.g. Aldicarb (Table 1). Common Natural nematicide in neem cake root exudates of marigold (Tagetes) in also found to be nematocidal Paeciliomyces fungi is also Neamalophagoui fungi, superheated steam is also used. The nanotechnology has the immense potential prospect of applications in agriculture and plants disease management in particular direct application of nanoparticles to soil or seed or foliage in the simplest to protect plants from different types of pathogen invasion by suppressing there as by the chemical methods. But a direct application of nanoparticles in soil and exposed parts of plants may also affect the on target organisms such as significant symbionts, solubilizers and nanoparticles may act as carriers of unwanted chemicals, concentrated intermediates of various pesticides/insecticides etc. [5]. Thus to reckon the scope and applications of nanoparticles in plant disease management the effect can be divided into two perspectives direct effect of nanoparticles on nematodes and use nanoparticles in formulating nematicides (Table 2). Due to their ultra-sub microscopic size nanoparticles gain the high degree of reactivity and sensitivity and thus have potential to prove very useful in control the PPNs, in addition, nematicidal residue analysis. As chemical and physical properties of nanoparticles vary greatly as compared to larger form, thus it has become imperative to evaluate the effect of nanoparticles on nematodes to harness the beneficial effects of this technology in the plant protection,

*Corresponding author: Rajni Kant Thakur, Department of Biotechnology, Dr. YS Parmar University of Horticulture and Forestry Nauni, Solan, India, Tel: 09805008033; E-mail: rajnithakur136@yahoo.in

Received August 02, 2017; Accepted August 21, 2017; Published August 28, 2017

Citation: Thakur RK, Shirkot P (2017) Potential of Biogold Nanoparticles to Control Plant Pathogenic Nematodes. J Bioanal Biomed 9: 220-222. doi:10.4172/1948593X.1000182

Copyright: ( 2017 Thakur RK, et al. This is an open-access article distributed under the terms of the Creative Commons Attribution License, which permits unrestricted use, distribution, and reproduction in any medium, provided the original author and source are credited. 
Citation: Thakur RK, Shirkot P (2017) Potential of Biogold Nanoparticles to Control Plant Pathogenic Nematodes. J Bioanal Biomed 9: $220-222$. doi:10.4172/1948-593X.1000182

\begin{tabular}{|c|c|c|}
\hline Chemical name & Trade name & Formulation \\
\hline Methyl bromide & Dowmigants & Gas \\
\hline 1,3 dichloropropene & Telone/DD-95 & Liquid \\
\hline Ethylene dibromide & Dowfume W-85 & Liquid \\
\hline Metam-sodium & Vapam & Liquid \\
\hline Dazomet & Basamid & Dust (prill) \\
\hline Methyl isothiocyanate & Di-Trapex & Liquid \\
\hline Chloropicrin & Larvacide & Liquid \\
\hline \multicolumn{3}{|c|}{ Organophosphates } \\
\hline Thionazin & Nemafos & Granular or emulsifiable liquid \\
\hline Ethoprophos & Mocap & Granular or emulsifiable liquid \\
\hline Fenamiphos & Nemacur & Granular or emulsifiable liquid \\
\hline Fensulfothion & Dasanit & Granular \\
\hline Terbufos & Counter & Granular \\
\hline Isazofos & Miral & Granular or emulsifiable liquid \\
\hline Ebufos & Rugby & Granular or emulsifiable liquid \\
\hline \multicolumn{3}{|c|}{ Carbamates } \\
\hline Aldicarb & Temik & Granular \\
\hline Aldoxycarb & Standak & Flowable \\
\hline Oxamyl & Vydate & Granular or emulsifiable liquid \\
\hline Carbofuran & Furadan/Curaterr & Granular or flowable \\
\hline Cleothocarb & Lance & Granular \\
\hline
\end{tabular}

Table 1: List of chemicals used as nematicides. especially against PPNs. Ultra small size and very high reactivity will affect the activity of PPNs [6]. Gold in different Variety of structure has been reportedly used in medicine since the history of civilization. Its compounds have been reported to be used in a treatment of various diseases such as rheumatism, lupus erythematosus, restorative dentistry, various skin disorder and even gold eyelid implants have been found the use for various medical conditions such as facial nerve palsy, lagophthalmos. In the modern time's nanostructures which possess and display variation in properties as compared to bulk gold. Due to their unique photocatalytic photothermal, optical and electrical properties and stability. The gold nanoparticles AuNPs have gained much significance in research since the last decade. AuNPs synthesized using various physical and chemical methods which are becoming less popular due to disadvantages of their expressiveness and nonecofriendly nature. Now bio gold nanoparticles syntheses by various biological organisms including bacteria are becoming popular as these overcome the disadvantages [7]. Cited above and highly stable AuNPs of different size and shapes can be synthesized using bacteria, fungi, actinomycetes, and yeast. Bacteria with their ability to reduce various metals grab target $\mathrm{Au}^{2+}$ ions from the environment and convert these into Au0 enzymatically. Various bacteria have been reported with the ability to synthesize AuNPs. An indigenous bacterial strain isolated from indigenous gold mines identified as Bacillus sp. GPI-2 was found to convert $\mathrm{AuCl}_{4}$ into AuNP of size $20 \mathrm{~nm}$ with the spherical shape. These

\begin{tabular}{|c|c|c|c|c|}
\hline Crop & Nematode pest & Nematicide & Application rate ${ }^{2}$ & Application techniques \\
\hline \multirow[t]{3}{*}{ Potato } & \multirow[t]{3}{*}{ Globodera sp. } & Aldi carb & $2.24-3.36$ & Incorporated in row \\
\hline & & Oxamyl & $4.0-5.5$ & - \\
\hline & & Carbofuran & $4.0-5.5$ & - \\
\hline \multirow{5}{*}{$\begin{array}{l}\text { Tomato, } \\
\text { cucurbits }\end{array}$} & \multirow[t]{4}{*}{ Meloidogyne spp. } & Aldi carb & 3.36 & Incorporated in $30 \mathrm{~cm}$ bands \\
\hline & & Ethoprophos & $0.9-2.9$ & Incorporated in bands \\
\hline & & Oxamyl & $0.6-1.2$ & Incorporated in bands \\
\hline & & Fenamiphos & $1.6-3.3$ & Incorporated in bands \\
\hline & Meloidogyne spp. & Dazomet & $30-50 \mathrm{~g} / \mathrm{m}^{2}$ & Incorporated in bands and irrigated time interval before planting \\
\hline \multirow[t]{2}{*}{ Citrus } & Tylenchulus semipenetrans & Fenamiphos & $10.8-21.6$ & Annual treatment applied along drip-line \\
\hline & Tylenchulus semipenetrans & Aldi carb & $5.5-11.0$ & Annual treatment applied along drip-line \\
\hline \multirow[t]{2}{*}{ Grape } & Xiphinema index & Aldi carb & 10-May & In band for nursery use \\
\hline & Meloidogyne spp. & fenamiphos (e.c. formulation) & 10 & In band for nursery useln band for nursery use \\
\hline \multirow[t]{5}{*}{ Banana } & Radophlus similis and/or & Carbofuran & 2-4 ga.i.per plant & Applied around plant 2-3 times per year \\
\hline & Helicotylenchus multicinctus and/or & Ethoprophos & 2-4 ga.i.per plant & Applied around plant 2-3 times per year \\
\hline & Pratylenchus spp. & Fenamiphos & 2-4 ga.i.per plant & Applied around plant 2-3 times per year \\
\hline & Meloidogyne spp. & Isazofos & 2-4 ga.i.per plant & Applied around plant 2-3 times per year \\
\hline & & Ebufos & 2-4 ga.i.per plant & Applied around plant 2-3 times per year \\
\hline
\end{tabular}

Table 2: List of Nematicides along with dose and application techniques for management of different nematodes.

\begin{tabular}{|l|l|l|}
\hline Organisms & Size $\mathbf{n m}$ & Author \\
\hline Bacillus licheniformis & 50 & Kalimuthu et al. (2008) \\
\hline Bacillus licheniformis (culture supernatant) & 50 & Kalishwaralal et al. (2008) \\
\hline Corynebacterium sp. & $10-15$ & Zang et al. (2005) \\
\hline Bacillus subtilis (culture supernatant) & $5-60$ & Saifuddin et al. (2009) \\
\hline Geobacter sulfurreducens & 200 & Law et al. (2008) \\
\hline Morganella sp. & $5-20$ & Parikh et al. (2008) \\
\hline Bacillus subtilis & $5-60$ & Saifuddin et al. (2009) \\
\hline Escherichia coli & $1-100$ & Gurunathan et al. (2009 a,b) \\
\hline Proteus mirabilis & $10-20$ & Samadi et al. (2009) \\
\hline Bacillus sp. & $5-15$ & Ganesh B abu and Gunasekaran (2009) \\
\hline Bacillus cereus & 4,5 & Pugazhenthiran et al. (2009) \\
\hline Staphylococcus aureus & $1-100$ & Nanda and Saravanan (2009) \\
\hline Brevibacterium casei & 50 & Kalishwaralal et al. (2010) \\
\hline Bacillus flexus & $20-40$ & Thakur and Shirkot (2017) \\
\hline
\end{tabular}

Table 3: List of microorganism synthesizing nanoparticles. 
Citation: Thakur RK, Shirkot P (2017) Potential of Biogold Nanoparticles to Control Plant Pathogenic Nematodes. J Bioanal Biomed 9: $220-222$. doi:10.4172/1948-593X.1000182

bio gold AuNPs were evaluated for their ability to kill nematodes [810]. As an active preparation, $\mathrm{AgNp}$ is well known to possess fungicidal and bacterial properties and thus used in the field of medicine, and are now catching attention in the fields of agriculture and horticulture. The Biological control agents play an important role in controlling the play pests like nematodes, weeds, insect, and mites [11].

Gold, Silver NP possess nematicidal activity that may provide an alternative to high-risk synthetic nematicides or inconsistent biological control agents. High frequency (biweekly) and high application doses $\left(\$ 90.4 \mathrm{mg} / \mathrm{m}^{2}\right.$ ) of Gold, Silver NP may be required to achieve effective field efficacy for root-knot nematode [12-17]. Combining AgNP with an irrigation system such as fertigation or tank-mixture with compatible chemicals that supplement the AgNP nematicidal effect may increase applicability of AgNP. Further understanding of the mechanism in the nematicidal action of Silver NP also warrants improvement of Gold, Silver NP efficacy (Table 3) [18-24].

\section{References}

1. Khan MR, Jain RK, Ghule TM, Pal S (2014) Root knot Nematodes in India-a comprehensive monograph. All India Coordinated Research Project on Plant Parasitic nematodes with the Integrated approach for their Control, Indian Agricultural Research Institute, New Delhi, India p: $78+29$ plates.

2. Pokharel RR, Larsen HJ (2007) The importance and management of phytoparasitic nematodes in western Colorado fruit orchards. J Nema 39: 96.

3. El-Sherif AM, Refaei AR, El-Nagar ME, Salem HM (2007) Society of nematologists 46th annual meeting, San Diego, California. J Nematol 39: 67104

4. Ladner DC, Tchounwou PB, Lawrence GW (2008) Evaluation of the effect of ecologic on root knot nematode, Meloidogyne incognita, and Tomato plant, Lycopersicon esculenum. Int J Environ Res Public Health 5: 104-110.

5. Singh S, Singh BK, SM, Gupta AK (2015) Applications of nanotechnology in agricultural and their role in disease management. Res $\mathrm{J}$ Nanosci Nanotech 5: $1-5$.

6. Gatoo MA, Naseem S, Arfat MY, Dar AM, Qasim K, et al. (2014) Physicochemical properties of nanomaterials: implication in associated toxic manifestations. BioMed Res Int 2014: 1-8.

7. Zhang XF, Liu ZG, Shen W, Gurunathan S (2016) Silver nanoparticles: synthesis, characterization, properties, applications, and therapeutic approaches. Int J Mol Sci 17: 1534

8. Aslani F, Bagheri S, Muhd Julkapli N, Juraimi AS, Hashemi FSG, et al. (2014) Effects of engineered nanomaterials on plants growth: an overview. Sci World J 2014: 28

9. Martínez-Ballesta MC, Zapata L, Chalbi N, Carvajal M (2016) Multiwalled carbon nanotubes enter broccoli cells enhancing growth and water uptake of plants exposed to salinity. J Nanobiotechnology 14: 42.
10. Siddiqi KS, Husen A (2017) Plant response to engineered metal oxide nanoparticles. Nanoscale Res Lett 12: 92.

11. Rico CM, Majumdar S, Duarte-Gardea M, Peralta-Videa JR, Gardea-Torresdey $\mathrm{JL}$ (2011) Interaction of nanoparticles with edible plants and their possible implications in the food chain. J Agric Food Chem 59: 3485-3498.

12. Kalimuthu K, Babu RS, Venkataraman D, Mohd B, Gurunathan S (2008) Biosynthesis of silver nanocrystals by Bacillus licheniformis. Colloids Surf B Biointerfaces 65: 150-153.

13. Kalishwaralal K, Deepak V, Ramkumarpandian S, Nellaiah H, Sangiliyand G (2008) Extracellular biosynthesis of silver nanoparticles by the culture supernatant of Bacillus licheniformis. Mater Lett 62: 4411-4413.

14. Zhang H, Li Q, Lu Y, Sun D, Lin X, et al. (2005) Biosorption and bioreduction of diamine silver complex by Corynebacterium. J Chem Technol Biotechnol 80 285-290.

15. Saifuddin N, Wong CW, Nur yasumira AA (2009) Rapid biosynthesis of silver nanoparticles using culture supernatant of bacteria with microwave irradiation. Eur J Chem 6: 61-70.

16. Law N, Ansari S, Livens FR, Renshaw JC, Lloyd JR (2008) The formation of nanoscale elemental silver particles via enzymatic reduction by Geobacter sulfurreducens. Appl Environ Microbiol 74: 7090-7093.

17. Parikh RY, Singh S, Prasad BL, Patole MS, Sastry M, et al. (2008) Extracellular synthesis of crystalline silver nanoparticles and molecular evidence of silver resistance from Morganella sp.: towards understanding biochemical synthesis mechanism. Chembiochem 9: 1415-1422.

18. Gurunathan S, Lee KJ, Kalishwaralal K, Sheikpranbabu S, Vaidyanathan R, et al. (2009) Antiangiogenic properties of silver nanoparticles. Biomaterials 30: 6341-6350.

19. Gurunathan S, Kalishwaralal K, Vaidyanathan R, Venkataraman D, Pandian SRK, et al. (2009) Biosynthesis, purification and characterization of silver nanoparticles using Escherichia coli. Colloids Surf B Biointerfaces 74: 328-335.

20. Samadi N, Golkaran D, Eslamifar A, Jamalifar H, Fazeli MR, et al. (2009) Intra/ extracellular biosynthesis of silver nanoparticles by an autochthonous strain of Proteus mirabilisisolated from photographic waste. J Biomed Nanotechnol 5: 247-253.

21. Ganesh Babu MM, Gunasekaran P (2009) Production and structural characterization of crystalline silver nanoparticles from Bacillus cereus isolate. Colloids Surf B Biointerfaces 74: 191-195.

22. Pugazhenthiran N, Anandan S, Kathiravan G, Prakash NKU, Crawford S, et al. (2009) Microbial synthesis of silver nanoparticles by Bacillus sp. J Nanopart Res 11: 1811-1815.

23. Nanda A, Saravanan M (2009) Biosynthesis of silver nanoparticles from Staphylococcus aureus and its antimicrobial activity against MRSA and MRSE. Nanomedicine 5: 452-456.

24. Thakur RK, Shirkot P (2017) Exploration of Western Himalayan region for identification of gold nanoparticles synthesizing bacteria. bioRxiv. 